$11-1-2018$

\title{
Market Share Growth and Stock Returns
}

Jaideep Chowdhury

Gokhan Sonaer

Umut Celiker

u.celiker@csuohio.edu

Follow this and additional works at: https://engagedscholarship.csuohio.edu/bus_facpub

Part of the Finance and Financial Management Commons

How does access to this work benefit you? Let us know!

Publisher's Statement

This is the peer reviewed version of the following article: Chowdhury, J., Sonaer, G., \& Celiker, U. (2018). Market share growth and stock returns. Accounting and Finance, 58, 97-129, which has been published in final form at https://doi.org/10.1111/acfi.12300. This article may be used for non-commercial purposes in accordance with Wiley Terms and Conditions for Use of SelfArchived Versions.

\section{Recommended Citation}

Chowdhury, Jaideep; Sonaer, Gokhan; and Celiker, Umut, "Market Share Growth and Stock Returns" (2018). Business Faculty Publications. 257.

https://engagedscholarship.csuohio.edu/bus_facpub/257

This Article is brought to you for free and open access by the Monte Ahuja College of Business at EngagedScholarship@CSU. It has been accepted for inclusion in Business Faculty Publications by an authorized administrator of EngagedScholarship@CSU. For more information, please contact library.es@csuohio.edu. 


\title{
Market share growth and stock returns
}

\author{
Jaideep Chowdhury $^{\mathrm{a}}$, Gokhan Sonaer ${ }^{\mathrm{b}}$, Umut Celiker ${ }^{\mathrm{c}}$
}

\section{Introduction}

A growing body of research on asset pricing reports that corporate events associated with asset expansion are followed by periods of lower stock returns (e.g. Loughran and Ritter, 1995; Rau and Vermaelen, 1998; Spiess and AffleckGraves, 1999). In the same vein, corporate events which lead to asset reduction are followed by subsequent higher stock returns (e.g. Michaely et al., 1995; Affleck-Graves and Miller, 2003). Asset growth effect on stock returns is reported by Cooper et al. (2008) and Polk and Sapienza (2009). These studies report a negative relationship between asset growth and subsequent stock returns and provide evidence consistent with a mispricing explanation. Lipson et al. (2009) attempt to explain this negative relationship between asset growth 
and stock returns based on two rational explanations, namely, compensation for risk and costly arbitrage.

In this paper, we examine the relationship between stock returns and a new growth variable, namely, market share growth of a firm. We define market share growth as industry-adjusted sales growth. This market share growth measure is widely used in another strand of literature that focuses on product market behaviour of the firms and its implications on corporate policies (e.g. Campello, 2003, 2006; Fresard, 2010). We introduce this new growth measure to the asset pricing literature.

We report a negative explanatory role for market share growth in explaining subsequent stock returns after controlling for all other known determinants of stock returns. Our findings are interesting, because they suggest that growth in market share is in fact harmful, rather than beneficial, to stockholder value. We also provide evidence indicating that market share growth and subsequent stock return relationship is mainly due to mispricing caused by overreaction of the investors.

We first perform portfolio analysis to examine the relationship between market share growth and stock returns. We sort firms into deciles based on their market share growth and find that firms in the lowest decile portfolio outperform the highest decile portfolio by an average monthly return of 0.853 percent in the subsequent year over the 1964-2012 period. Our results are robust to various subperiods, specifically, 1964-1979, 1980-1995 and 19962012 and various risk adjustments.

It is possible that firm-specific characteristics such as size, book-to-market, past returns and asset growth, which are known to affect stock returns, might be driving our results. In order to explore this possibility, we perform bivariate analyses by forming double-sorted portfolios. We show that the negative association between market share growth and subsequent stock returns is not driven by these characteristics.

We next undertake multivariate analysis in order to explore the potential additional explanatory power of market share growth in explaining stock returns beyond the other variables that are suggested to have explanatory power. We employ the standard Fama-Macbeth regression methodology and estimate regression equations with average monthly stock returns as the dependent variable and market share growth as the independent variable, with beta of a firm, size, book-to-market, past cumulative returns and asset growth as control variables. We report that even after controlling for beta, size, bookto-market, past cumulative returns and asset growth, future stock returns are strongly negatively related to current market share growth.

We believe that our results can be explained by investors' overreaction and subsequent correction as has been suggested by Cooper et al. (2008) and Skinner and Sloan (2002). Investors are overly optimistic about the prospects of the high market share growth firms. The investors overreact to the good news that these firms have high market share growth coupled with good 
operating performance in the quarter in which market share growth is measured. They expect that the firms will maintain the good operating performance in the future. However, the firms with high market share growth experience deterioration of operating performance in the subsequent periods. Investors are surprised by the worsening operating performance. They realise that their expectations about these firms are not met, leading to subsequent corrections in investors' expectations and lower stock market returns. Consistent with this argument, we report that the firms with highest market share growth suffer from reduction in both operational profit margin and net profit margin in subsequent quarters. Firms with the highest market share growth also experience reversals in SUEs, with SUEs decreasing from 28.59 percent in the quarter in which market share growth is measured to -16.39 percent in the subsequent 6th quarter. We also document that average daily returns around earnings announcement days are significantly lower than average daily returns excluding announcements days in the subsequent quarters. This evidence suggests that investors are surprised by the deteriorating earnings of these firms. The reduction in both operational and net profit margin and reversals in SUEs buttress our argument about the unsustainability of the good operating performance for the firms with high market share growth resulting in corrections in investors' initial overreaction and ultimately leading to lower subsequent stock market returns.

A similar argument can be put forward for firms with low market share growth. These firms report poor operating performance and high negative SUEs in the quarter when market share is measured. Investors overact to the bad news about these firms and expect that their poor operating performance will continue. However, these firms experience improvement in both operating profit margin and net profit margin in the subsequent quarters. ${ }^{1}$ These firms also report increase in SUEs. We report that SUEs for lowest market share firms increase from -35.78 percent in the quarter when market share is measured to +6.98 percent in the subsequent 6 th quarter. Our results indicate that the investors are surprised by the improved earnings. With these positive news, overpessimism about these firms subsides, resulting in good stock market performance in the subsequent quarters.

This study is closely related to Lakonishok et al. (1994, hereafter LSV), who examine the returns to various value strategies and explore the potential explanations why such value strategies outperform glamour strategies. One of the measures that LSV use to define value and glamour stocks is the 5-year average sales growth $(\mathrm{G} / \mathrm{S})$. In addition to this $\mathrm{G} / \mathrm{S}$ measure, they employ other alternative measures such as the ratio of book value of equity to market value of equity $(\mathrm{B} / \mathrm{M})$, the ratio of cash flow to market value of equity $(\mathrm{C} / \mathrm{P})$, the ratio 
Panel A Operating profit margin

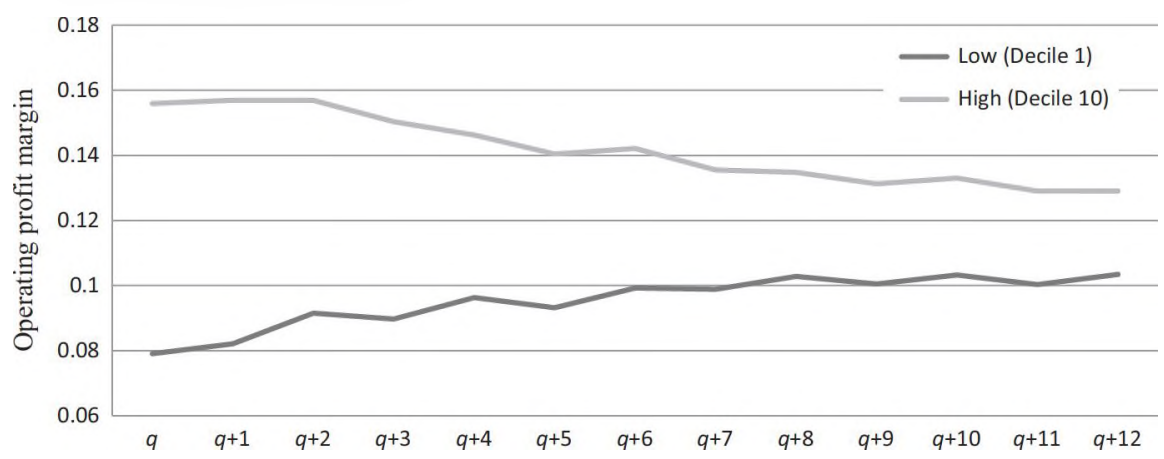

\section{Panel B Net profit margin}

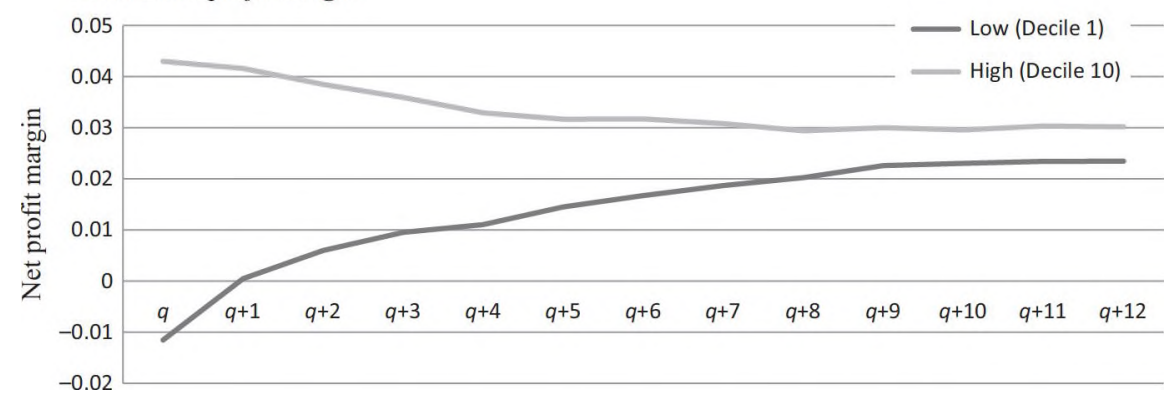

Figure 1 Profit margin and quarterly market share growth. At the end of each quarter $q$ during the 1964-2012 period, we sort all stocks in our sample into deciles based on previous fiscal quarter market share growth using the quarterly financial statements. Quarterly market share growth is defined as in Table 7. We plot the operating profit margin and net profit margin in panels (a) and (b), respectively, for the lowest (Decile 1) and highest (Decile 10) quarterly market share growth deciles for the quarters $q$ to $q+12$. Operating profit margin is defined as operating income before depreciation (Compustat data item OIBDPQ) divided by contemporaneous quarter net sales (Compustat data item SALEQ). Net profit margin is defined as income before extraordinary items (Compustat data item IBQ) divided by contemporaneous quarter net sales.

of earnings to market value of equity $(\mathrm{E} / \mathrm{P})$ to categorise firms into value and glamour portfolios. They define the stocks with the lowest (highest) B/M or C/ $\mathrm{P}$ or $\mathrm{E} / \mathrm{P}$ or highest (lowest) $\mathrm{G} / \mathrm{S}$ as glamour(value) portfolios. Their main findings are that the value portfolios outperform the glamour portfolios over the April 1968 to April 1990 period and this outperformance cannot be explained by differences in risk. Although our results are in line with LSV's findings, our study differs from LSV in three main ways. First, we perform a more detailed analysis of the effect of market share growth on subsequent stock returns compared to LSV, as their focus is broader, specifically, how the value portfolios outperform the glamour strategies. G/S measure is only one of the 
four measures they use to define value and glamour stocks. In contrast, the focus of this study is solely on the relationship between market share growth and subsequent stock returns. ${ }^{2}$ Second, our measure of market share growth is different from LSV's measure of sales growth $(\mathrm{G} / \mathrm{S})$. We perform two separate robustness tests to ensure that our results based on market share growth are not subsumed by the sales growth measure of LSV. Third, our paper provides evidence in support of behavioural explanation for the negative association between market share growth and subsequent stock returns.

The rest of the paper is organised as follows. In Section 2, we describe the data and sample construction. In Section 3, we explain the methodology used in the paper and also discuss the results. In Section 4, we offer a potential explanation of our results. In Section 5, we perform robustness test and we provide our conclusion in Section 6.

\section{Data and sample construction}

In this study, we use data from three sources. Our monthly stock returns data are from CRSP through WRDS. Financial statement data are from the COMPUSTAT annual and quarterly data files. Our sample consists of all stocks in the merged CRSP and COMPUSTAT databases over the 1964-2012 periods after several filters. To focus on common stocks, we only include stocks with share codes 10 and 11 . We exclude all firms with annual sales less than $\$ 5,000,000$. We also exclude all financial services companies (SIC codes 6000 6999). Industries are classified based on first two-digit SIC codes. The analyst measure data are obtained from $\mathrm{I} / \mathrm{B} / \mathrm{E} / \mathrm{S}$ database.

\subsection{Market share growth}

Following Fresard (2010), we define market share growth as

$$
M S G_{i, t}=\frac{\text { Sales }_{i, t}-\text { Sales }_{i, t-1}}{\text { Sales }_{i, t-1}}-A V S G_{j, t},
$$

where Sales $_{i, t}$ is the total revenues of firm $i$ in fiscal year $t$ and $A V S G_{\bar{j}, t}$ is the average sales growth for industry $j$ in fiscal year $t$. We also define this measure using quarterly financial statements. Quarterly market share growth is defined as 


$$
\operatorname{QMSG}_{i, q}=\frac{\text { QSales }_{i, q}-\text { QSales }_{i, q-4}}{\text { QSales }_{i, q-4}}-A V Q S G_{j, q}
$$

where QSales $s_{i-q}$ is the quarterly revenues of firm $i$ in quarter $q$ and $A V Q S G_{i-q}$ is the average sales growth for industry $j$ in quarter $q .{ }^{3}$

\section{Methodology and results}

We employ univariate portfolio analysis to examine the relationship between market share growth and future stocks returns. To control for other characteristics that may affect stock returns, we also perform bivariate portfolio analysis and multivariate Fama-Macbeth regressions.

\subsection{Market share growth and stock returns - univariate analysis}

In June of year $t$, we sort all stocks in our sample into deciles based on previous fiscal year's market share growth. Monthly equal-weighted stock returns for the ten portfolios are calculated. In panel $\mathrm{A}$ of Table 1 , we report the average monthly returns in excess of the risk-free rate, three- and four-factor alphas for the low (Decile 1) and the high (Decile 10) market share growth deciles and the difference portfolio that buys highest market share growth portfolio and sells short lowest market share growth portfolio (High-Low). The last row of the table reports the $p$ values for the difference portfolio's average excess returns, and three- and fourfactor alphas. These portfolios are reformed in June of year $t+1$. We report a negative association between market share growth and subsequent average excess monthly returns and three/four-factor alphas. The differences in average excess monthly returns, Fama-French three-factor (Fama and French, 1993) alphas and Carhart four-factor (Carhart, 1997) alphas between the first and the last deciles are negative and statistically significant as reported in the last two rows of the table. ${ }^{4}$

Cooper et al. (2008) report that asset growth can explain the subsequent stock market returns. One potential explanation of the negative association between market share growth and subsequent stock returns is that our results are a manifestation of the results of Cooper et al. (2008). It is possible that asset 
Table 1

Market share growth and subsequent stock returns

Panel A. Excess returns, three- and four-factor alphas

\begin{tabular}{lccc}
\hline Market share growth & Excess returns & Three-factor alphas & Four-factor alphas \\
\hline Low & $1.230^{* * * *}$ & $0.370^{* * *}$ & $0.588^{* * *}$ \\
High & 0.377 & $-0.394^{* * *}$ & -0.086 \\
High-Low & $-0.853^{* * *}$ & $-0.764^{* * *}$ & $-0.674^{* * *}$ \\
$p$-value & $<0.00001$ & $<0.00001$ & $<0.00001$ \\
\hline
\end{tabular}

Panel B. Alphas - asset growth (AG) factor

\begin{tabular}{lccc}
\hline Market share growth & AG factor & Three-factor + AG Factor & Four-factor + AG Factor \\
\hline Low & $1.606^{* * *}$ & $0.349^{* * *}$ & $0.548^{* * *}$ \\
High & $0.979^{* * *}$ & $-0.270^{* *}$ & 0.011 \\
High-Low & $-0.626^{* * *}$ & $-0.618^{* * *}$ & $-0.538^{* * *}$ \\
$p$-value & $<0.00001$ & $<0.00001$ & $<0.00001$ \\
\hline
\end{tabular}

This table presents the average monthly returns in excess of the risk-free rate and the abnormal returns earned by portfolios based on market share growth constructed with all NYSE, AMEX and NASDAQ common stocks for the 1964-2012 period after excluding all financial stocks and firms with annual sales less than $\$ 5$ million. In June of year $t$, we sort all stocks in our sample into deciles based on previous fiscal year market share growth. Market share growth is defined as $M S G_{i, t}=\frac{{\text { Sales } s_{i, t}-\text { Sales }_{i,-1}}_{\text {Sales }_{i,-1}}-A V S G_{j, t} \text {, where Sales }}{i, t}$ is the total revenues of firm $i$ in fiscal year $t$ and $A V S G_{j, i}$ is the average sales growth for ind ustry $j$ in fiscal year $t$. Monthly equal-weighted stock returns for the ten portfolios and the difference portfolio that buys highest market share growth portfolio and sells short lowest market share growth portfolio (High-Low) are calculated from July of year $t$ to June of year $t+1$. These portfolios are reformed in June of year $t+1$. Panel A presents the average monthly returns in excess of the risk-free rate, three- and four-factor alphas for the low (Decile 1) and the high (Decile 10) market share growth deciles and the difference portfolio that buys highest market share growth portfolio and sells short lowest market share growth portfolio (High-Low). The last row of the table reports the $p$-values for the difference portfolio's average returns, and three- and four-factor alphas. $p$ values are calculated from Student's $t$-test. Panel B presents the one-factor (asset growth factor), four-factor (Fama-French three-factor + asset growth factor) and the five-factor (Carhart four-factor + asset growth factor) alphas for the same portfolios. In order to create an asset growth factor, in June of year $t$, we sort all stocks in our sample into two based on their market capitalisation. In each size group, we then sort the stocks into tertiles based on previous fiscal year asset growth. We calculate the monthly valueweighted stock returns for the six ( 2 size $\times 3$ asset growth) portfolios from July of year $t$ to June of year $t+1$. We then compute the equal-weighted average returns for each asset gro

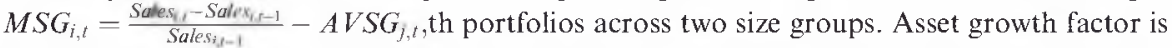
the difference between monthly returns to high asset growth stocks and low asset growth stocks. Excess returns and the alphas are in percentages. ${ }^{*}, * *, * * *$ indicate significance at the 10,5 and 1 percent levels, respectively. 
growth largely subsumes the effect of market share growth. In order to mitigate any concern that the results with respect to market share growth are reflective of the results in terms of asset growth, we repeat the analysis of panel A of Table 1 with a new factor, called the asset growth factor.

In June of year $t$, we sort the stocks into deciles based on previous fiscal year market share growth. In order to create an asset growth factor, in June of year $t$, we sort all stocks in our sample into two groups based on their market capitalisation. In each size group, we then sort the stocks into tertiles based on previous fiscal year asset growth. We calculate the monthly value-weighted stock returns for the six ( 2 size $\times 3$ asset growth) portfolios from July of year $t$ to June of year $t+1$. We then compute the equal-weighted average returns for each asset growth portfolios across two size groups. Asset growth factor is the difference between monthly returns to high asset growth stocks and low asset growth stocks.

Panel B of Table 1 presents the one-factor (asset growth factor), four-factor (Fama-French three-factor + asset growth factor) and the five-factor (Carhart four-factor + asset growth factor) alphas for the same portfolios. The results are similar to those reported in panel A. We report that the low (high) portfolios based on market share growth have high (low) asset growth (AG, hereafter) factor alphas, three-factor plus $A G$ factor alphas and four-factor plus AG factor alphas. The difference portfolio that buys highest market share growth portfolio and sells short lowest market share growth portfolio (HighLow) has a negative and statistically significant AG factor alpha, three-factor plus $A G$ factor alpha and four-factor plus $A G$ factor alpha.

The results in Table 1 suggest a negative relationship between market share growth and the next year's monthly excess and risk-adjusted stock returns. This negative association is robust even after the inclusion of the asset growth factor.

In order to disseminate any possible time patterns in these negative associations, we divide our sample period into three subperiods, namely 1964-1979, 1980-1995 and 1996-2012. We report the results for these three subperiods in Table 2 . We find a negative association between the market share growth at year $t-1$ and the average monthly excess returns in the subsequent year with the difference portfolio (High-Low)'s average monthly returns being negative and statistically significant for all the three subperiods. For each of the three panels in Table 2, we sort all stocks in our sample into deciles in June of year $t$ based on previous fiscal year market share growth and monthly equalweighted stock returns are formed. The second last row of all the panels reports the results for the difference portfolio that buys highest market share growth portfolio and sells short lowest market share growth portfolio (High-Low). These portfolios are reformed in June of year $t+1$. In Panel A of Table 2, the average monthly returns for the low market share growth, high market share growth, and the difference portfolios are reported for all the three subperiods. In Panel B (C) of Table 2, we report the corresponding three (four)-factor alphas for these portfolios. Our results indicate that the difference portfolio earns negative raw and risk-adjusted returns in all three subperiods. 
Overall, our results suggest a negative association between the market share growth and subsequent year's average monthly excess and abnormal returns, and these negative associations are robust to various subperiod classifications.

\subsection{Market share growth and stock returns - bivariate analyses}

It is possible that the negative association between previous fiscal year's market share growth and the stock returns in the subsequent year is driven by other firm characteristics, which are reported to impact the stock market returns. One such firm characteristic is the firm size. Previous studies show that there is significant

Table 2

Market share growth and stock returns - subperiods

\begin{tabular}{lccc}
\hline Mkt. share growth & $1964-1979$ & $1980-1995$ & $1996-2012$ \\
\hline Panel A. Excess returns & & & \\
\hline Low & $1.365^{* *}$ & $0.866^{* *}$ & $1.450^{* *}$ \\
High & 0.604 & 0.143 & 0.391 \\
High-Low & $-0.761^{* * *}$ & $-0.723^{* * *}$ & $-1.059^{* * *}$ \\
-value & 0.00003 & 0.00002 & $<0.00001$ \\
\hline
\end{tabular}

Panel B. Three-factor alphas

\begin{tabular}{lccc}
\hline Low & $0.294^{* *}$ & 0.060 & $0.627^{* *}$ \\
High & $-0.254^{* *}$ & $-0.538^{* * *}$ & -0.383 \\
High-Low & $-0.548^{* * *}$ & $-0.598 * * *$ & $-1.010 * * *$ \\
p-value & 0.00039 & 0.00002 & $<0.00001$ \\
\hline Panel C. Four-factor alphas & & & \\
\hline Low & $0.384 \% * * *$ & $0.094 \%$ & $0.858 \% * * *$ \\
High & $-0.065 \%$ & $-0.403 \% * * *$ & $-0.078 \%$ \\
High-Low & $-0.449 \% * * *$ & $-0.497 \% * * *$ & $-0.935 \% * * *$ \\
$p$-value & 0.00453 & 0.00045 & $<0.00001$ \\
\hline
\end{tabular}

This table presents the average monthly returns and three- and four-factor alphas earned by portfolios based on market share growth constructed with all NYSE, AMEX and NASDAQ common stocks for the for the three subperiods, 1964-1979, 1980-1995 and 1995-2012. All financial stocks and firms with annual sales less than $\$ 5$ million are excluded from our sample. Market share growth portfolios are constructed as described in Table 1. Panel A presents the average monthly returns in excess of the risk-free rate for the bottom (low) and top (high) deciles and the difference portfolio that buys highest market share growth portfolio and sells short lowest market share growth portfolio (High-Low). Panels B and C present the threeand four-factor alphas, respectively. The last row reports the $p$-values for the difference portfolio's average returns, and three- and four-factor alphas, in panels A, B and C, respectively. Excess returns, three-factor alphas and four-factor alphas are in percentages. *, $* * * * *$ indicate significance at the 10,5 and 1 percent levels, respectively. 
relationship between size and stock returns (see Banz, 1981; Reinganum, 1981). To control for firm size, for each year $t$, we categorise stocks in our sample with end-of-June market capitalisation below 30th percentile as small, between 30th and 70th percentile as medium, and above 70th percentile as large stocks. We then separately sort the stocks in these three size groups into deciles based on previous fiscal year's market share growth. As before, these portfolios are equal-weighted and reformed in June of each year. Table 3 presents the average monthly excess returns and three- and four-factor alphas earned by the bottom (lowest) and top (highest) market share growth portfolios and difference portfolio for the three size groups during 1964-2012 period. Panel A presents the average monthly excess returns. Consistent with the previous results, we report a negative association between market share growth at year $t-1$ and average monthly excess returns in the subsequent year for all size groups, with the difference portfolio (High-Low)'s average monthly returns being negative and statistically significant. Panels B and C present the three- and four-factor alphas, respectively, for the three size groups. We also report a negative relationship between the three/ four-factor alphas and market share growth for all the three size deciles.

The results documented in Table 3 suggest that the negative association between market share growth and the following year's stock returns is not driven by firm size as the negative associations are reported for all the three size groups.

Book-to-market (hereafter BM) is another factor which has been reported to affect stock returns (see Chen, 2012; for a risk-based explanation of book-tomarket). In order to control for BM effect, for each year $t$, we categorise stocks in our sample with previous fiscal year-end's BM below 30th percentile as low, between 30th and 70th percentile as intermediate, and above 70th percentile as high BM stocks, where BM is defined as the ratio of book value of equity to market value of equity. We then separately sort the stocks in these three BM groups into deciles based on previous fiscal year's market share growth similar to the previous analysis. In Table 4, we document the average excess monthly returns and three- and four-factor alphas earned by the bottom (lowest) and top (highest) market share growth decile portfolios and the difference portfolio constructed for low, intermediate and high book-to-market (BM) stocks during 1964-2012. Panel A presents the average excess monthly returns. Panels B and $\mathrm{C}$ present the subsequent three- and four-factor alphas, respectively, for the three BM groups. We report a negative association between market share growth and following year's average excess raw returns and three/four-factor alphas for all the three groups based on BM. In addition, the difference portfolio's average monthly returns and three/four-factor alphas are negative and statistically significant for all the three groups of BM.

The results presented in Table 4 suggest that our results of negative association between the market share growth and following year's average monthly returns and three/four-factor alphas are not driven by BM.

Past cumulative returns are also reported to affect the stock returns (see Jegadeesh and Titman, 1993; Chan, Jegadeesh and Lakonishok, 1999). We 
Table 3

Market share growth and firm size

\begin{tabular}{lccc}
\hline Mkt. share growth & Small & Medium & Large \\
\hline Panel A. Excess returns & & & \\
\hline Low & $1.686^{* * *}$ & $0.935^{* * *}$ & $0.744^{* * *}$ \\
High & $0.731^{* *}$ & 0.230 & 0.362 \\
High-Low & $-0.955^{* * *}$ & $-0.705^{* * *}$ & $-0.382^{* * *}$ \\
-value & $<0.00001$ & $<.00001$ & 0.00688 \\
\hline
\end{tabular}

Panel B. Three-factor alphas

\begin{tabular}{lccc}
\hline Low & $0.688^{* * *}$ & 0.099 & 0.093 \\
High & -0.177 & $-0.596^{* * *}$ & $-0.206^{* *}$ \\
High-Low & $-0.865^{* * *}$ & $-0.695^{* * *}$ & $-0.300^{* * *}$ \\
$p$-value & $<0.00001$ & $<0.00001$ & 0.00603 \\
\hline
\end{tabular}

Panel C. Four-factor alphas

\begin{tabular}{lllc}
\hline Low & $0.925^{* * *}$ & $0.290^{* * *}$ & $0.249 * * *$ \\
High & 0.146 & $-0.238^{*}$ & 0.030 \\
High-Low & $0.779 * * *$ & -0.528 & $-0.220 * * *$ \\
$p$-value & 0.00001 & $<0.00001$ & 0.04619 \\
\hline
\end{tabular}

This table presents the average monthly returns and three- and four-factor alphas earned by portfolios based on market share growth constructed for small, medium and large stocks during 1964-2012. Each year $t$, we categorise stocks in our sample with end-of-June market capitalisation below 30 th percentile as small, between 30 th and 70 th percentile as medium, and above 70 th percentile as large stocks. We then separately sort the stocks in these three size groups into deciles based on previous fiscal year market share growth. Market share growth is as defined in Table 1 . Monthly equal-weighted stock returns for the bottom (low) and top (high) deciles and the difference portfolio that buys highest market share growth portfolio and sells short lowest market share growth portfolio (High-Low) are calculated from July of year $t$ to June of year $t+1$, for each size group. These portfolios are reformed in June of year $t+1$. Panel A presents the average monthly returns in excess of the risk-free rate. Panels $\mathbf{B}$ and $\mathbf{C}$ present the three- and four-factor alphas, respectively, for the three size groups. The last row reports the $p$-values for the difference portfolio's a verage returns, and three- and four-factor alphas, in panels A, B and C, respectively. Excess returns, three-factor alphas and four-factor alphas are in percentages. *,**,*** indicate significance at the 10,5 and 1 percent levels, respectively.

need to ensure that our results are not driven by past cumulative returns. Table 5 presents the average excess monthly returns and three- and four-factor alphas earned by portfolios based on market share growth with low, intermediate and high past cumulative returns during the period of 19642012. For each month $m$ from July of year $t$ to June of year $t+1$, we categorise stocks in our sample with cumulative past returns from month $m-12$ to $m-1$ below 30th percentile as low, between 30th and 70th percentiles as intermediate, and above 70 th percentile as high past cumulative return stocks. For each 
Table 4

Market share growth and BM

\begin{tabular}{lcrr}
\hline Mkt. share growth & Low BM & Inter. BM & High BM \\
\hline Panel A. Excess returns & & & \\
\hline Low & & $1.159^{* * *}$ & $1.656^{* * *}$ \\
High & $0.630^{*}$ & $0.566^{*}$ & $1.031^{* * *}$ \\
High-Low & 0.039 & $-0.593^{* * *}$ & $-0.625^{* * *}$ \\
-value & $-0.590^{* * *}$ & $<0.00001$ & 0.00001 \\
\hline
\end{tabular}

Panel B. Three-factor alphas

\begin{tabular}{lccc}
\hline Low & -0.048 & $0.335^{* * *}$ & $0.663 * * *$ \\
High & $-0.635^{* * *}$ & $-0.287^{* *}$ & 0.114 \\
High-Low & $-0.587 * * *$ & $-0.622^{* * *}$ & $-0.549 * *$ \\
$p$-value & 0.00008 & $<0.00001$ & 0.00011 \\
\hline
\end{tabular}

Panel C. Four-factor alphas

\begin{tabular}{lccc}
\hline Low & 0.183 & $0.527^{* * *}$ & $0.867^{* * *}$ \\
High & $-0.272^{* *}$ & -0.012 & $0.348^{* * *}$ \\
High-Low & $-0.455^{* * *}$ & $-0.538^{* * *}$ & $-0.518^{* * *}$ \\
$p$-value & 0.00224 & $<0.00001$ & 0.00035 \\
\hline
\end{tabular}

This table presents the average monthly returns and three- and four-factor alphas earned by portfolios based on market share growth constructed for low, intermediate and high book-tomarket (BM) stocks during 1964-2012. Each year $t$, we categorise stocks in our sample with previous fiscal year-end BM below 30 th percentile as low, between 30 th and 70 th percentiles as intermediate and above 70 th percentile as high BM stocks. We then separately sort the stocks in these three BM groups into deciles based on previous fiscal year market share growth. Market share growth is as defined in Table 1. Monthly equal-weighted stock returns for the bottom (low) and top (high) deciles and the difference portfolio that buys highest market share growth portfolio and sells short lowest market share growth portfolio (HighLow) are calculated from July of year $t$ to June of year $t+1$, for each BM group. These portfolios are reformed in June of year $t+1$. Panel A presents the average monthly returns in excess of the risk-free rate. Panels B and $C$ present the three- and four-factor alphas, respectively, for the three $\mathrm{BM}$ groups. The last row reports the $p$-values for the difference portfolio's average returns, and three- and four-factor alphas, in panels A. B and C, respectively. Excess returns, three-factor alphas and four-factor alphas are in percentages. Excess returns, three-factor alphas and four-factor alphas are in percentages. *,***** indicate significance at the 10,5 and 1 percent levels, respectively.

cumulative past return group, monthly equal-weighted stock returns for the ten market share growth portfolios and the difference portfolio that buys highest market share growth portfolio and sells short lowest market share growth portfolio (High-Low) are calculated from July of year $t$ to June of year $t+1$. Market share growth portfolios are constructed based on previous fiscal year's market share growth. Panel A of Table 5 presents the average excess monthly 
returns earned by the bottom (lowest) and top (highest) market share growth decile portfolios and the difference portfolio with low, intermediate and high cumulative past returns during the period of 1964-2012. Panels B and C present three- and four-factor alphas, respectively, for the three past cumulative return groups. The difference portfolio earns negative statistically significant average excess monthly returns, with the three- and four-factor alphas also negative and statistically significant for the low and intermediate past cumulative return groups. Although the raw excess return of this difference portfolio for the high past return group is negative and significant, the three- and four-factor alphas are negative but not statistically significant.

The results reported in Table 5 suggest that our results of negative association between market share growth and next year's average monthly returns and three/four-factor alphas exists in all the three groups based on past cumulative returns; however, this relationship is more prominent in stocks with low and intermediate past cumulative returns.

Cooper et al. (2008) show that there is negative association between asset growth and subsequent returns. To control for asset growth effect on stock returns in Section 3.1, we estimate asset growth factor-adjusted alphas and report the results in Table 1. In this section, we employ an alternative methodology to control for asset growth effect. For each year $t$, we categorise stocks in our sample with previous fiscal year' asset growth (AG) below 30th percentile as low, between 30th and 70th percentiles as intermediate, and above 70th percentile as high $A G$ stocks. $A G$ is defined as $\left(T A_{t}-T A_{\mathrm{t}-1}\right) / T A_{t-1}$, where $T A_{t}$ is the total assets of the firm at the end of the fiscal year $t$. We then separately sort the stocks in these three AG groups into deciles based on previous fiscal year's market share growth similar to the above analyses that control for size, BM and past cumulative returns. For each AG group, monthly equal-weighted stock returns in excess of the risk-free rate for bottom (lowest) and top (highest) market share growth portfolios and the difference portfolio that buys highest market share growth portfolio and sells short lowest market share growth portfolio (High-Low) are calculated from July of year $t$ to June of year $t+1$. The results of this analysis are reported in Table 6 . The difference portfolio earns negative and statistically significant excess and risk-adjusted returns especially for the high AG stocks. For the low AG firms, the excess and risk-adjusted returns of the difference portfolio are still negative, albeit not statistically significant.

\subsection{Market share growth and stock returns - multivariate analysis}

In order to explore the possible explanatory role of market share growth in explaining subsequent average monthly returns, while controlling for other factors, we perform a multivariate analysis. Following several papers including Cooper et al. (2008), we employ Fama-Macbeth regression methodology.

Table 7 presents the coefficients from Fama-Macbeth regressions and the corresponding $p$-values for the period of 1964-2012 of monthly stock returns on market share growth (MKTSHRG) and several control variables, which are 
Table 5

Market share growth and past cumulative returns

\begin{tabular}{lccc}
\hline Mkt. share growth & Low Past Ret. & Inter. Past Ret. & High Past Ret. \\
\hline Panel A. Excess returns & & & \\
\hline Low & $1.281^{* * *}$ & $1.032^{* * *}$ & $1.526^{* * *}$ \\
High & -0.285 & 0.318 & $1.180^{* * *}$ \\
High-Low & $-1.566^{* * *}$ & $-0.715^{* * *}$ & $-0.347^{* *}$ \\
$p$-value & $<0.00001$ & $<0.00001$ & 0.01506 \\
\hline
\end{tabular}

Panel B. Three-factor alphas

\begin{tabular}{lccc}
\hline Low & 0.277 & 0.185 & $0.759 * * *$ \\
High & $-1.175 * * *$ & $-0.435 * * *$ & $0.540^{* * *}$ \\
High-Low & $-1.452 * * *$ & $-0.620 * * *$ & -0.219 \\
$p$-value & $<0.00001$ & $<0.00001$ & 0.11315 \\
\hline
\end{tabular}

Panel C. Four-factor alphas

\begin{tabular}{lccc}
\hline Low & $0.910^{* * *}$ & $0.309^{* * *}$ & $0.527^{* * *}$ \\
High & $-0.478^{* * *}$ & $-0.251^{* *}$ & $0.316^{* * *}$ \\
High-Low & $-1.388^{* * *}$ & $-0.561 * * *$ & -0.211 \\
$p$-value & $<0.00001$ & 0.00001 & 0.13542 \\
\hline
\end{tabular}

This table presents the average monthly returns and three- and four-factor alphas earned by portfolios based on market share growth with low, intermediate and high cumulative past returns during 1964-2012. In June of year $t$, we sort all stocks in our sample into deciles based on previous fiscal year market share growth. Market share growth is as defined in Table 1. Each month $m$ from July of year $t$ to June of year $t+1$, we categorise stocks in our sample with cumulative past returns from month $m-12$ to $m-1$ below 30 th percentile as low, between 30 th and 70 th percentile as intermediate and above 70 th percentile as high past cumulative return stocks. For each cumulative past return group, monthly equal-weighted stock returns for bottom (low) decile and top (high) decile portfolios and the difference portfolio that buys highest market share growth portfolio and sells short lowest market share growth portfolio (High-Low) are calculated from July of year $t$ to June of year $t+1$. These portfolios are reformed in June of year $t+1$. Panel A presents the average monthly returns in excess of the risk-free rate. Panels B and $C$ present the three- and four-factor alphas, respectively, for the three past cumulative return groups. The last row reports the $p$-values for the difference portfolio's average returns, and three- and four-factor alphas, in panels A, B and C, respectively. Excess returns, three-factor alphas and four-factor alphas are in percentages. $*_{,}, *, * *$ indicate significance at the 10,5 and 1 percent levels, respectively.

known to affect stock returns. The reported coefficients are the time-series averages of the monthly regression coefficients for the 1964-2012 period. $p$-values are calculated using the Newey-West autocorrelation-adjusted standard errors, where the lag is set to $4 .^{5}$ 
Table 6

Market share growth and asset growth

\begin{tabular}{lccc}
\hline Mkt. share growth & Low asset growth & Inter. asset growth & High asset growth \\
\hline Panel A. Excess returns & & & \\
\hline Low & $1.534^{* * *}$ & $1.084^{* * *}$ & $0.742^{* *}$ \\
High & $1.320^{* * *}$ & $0.899^{* * *}$ & -0.033 \\
High-Low & -0.214 & $-0.184^{*}$ & $-0.775^{* * *}$ \\
$p$-value & 0.17399 & 0.05543 & $<0.00001$ \\
\hline
\end{tabular}

Panel B. Three-factor alphas

\begin{tabular}{lccc}
\hline Low & $0.566^{* * *}$ & $0.370^{* * *}$ & -0.015 \\
High & $0.515^{* * *}$ & 0.138 & $-0.777^{* * *}$ \\
High-Low & -0.051 & $-0.232^{* *}$ & $-0.761^{* * *}$ \\
$p$-value & 0.74023 & 0.01773 & $<0.00001$ \\
\hline
\end{tabular}

Panel C. Four-factor alphas

\begin{tabular}{lccc}
\hline Low & $0.800^{* * *}$ & $0.475^{* * *}$ & $0.236^{*}$ \\
High & $0.662^{* * *}$ & $0.282^{* * *}$ & $-0.335^{* *}$ \\
High-Low & -0.138 & -0.192 & $-0.570^{* * *}$ \\
$p$-value & 0.37747 & $0.05341^{*}$ & 0.00002 \\
\hline
\end{tabular}

This table presents the average monthly returns and three- and four-factor alphas earned by portfolios based on market share growth constructed for low, intermediate and high asset growth stocks during 1964-2012. In June of year $t$, we categorise stocks in our sample with previous fiscal year asset growth below 30 th percentile as low, between 30 th and 70 th percentile as intermediate and above 70th percentile as high asset growth stocks. Asset growth is defined as $\left(T A_{t}-T A_{t-1}\right) / T A_{t}$, where $T A_{i}$ is the total assets of the firm at the end of the fiscal year $t$. We then separately sort the stocks in these three asset growth groups into deciles based on previous fiscal year market share growth. Market share growth is as defined in Table 1. Monthly equalweighted stock returns for the bottom (low) and top (high) deciles and the difference portfolio that buys highest market share growth portfolio and sells short lowest market share growth portfolio (High-Low) are calculated from July of year $t$ to June of year $t+1$, for each sales growth group. These portfolios are reformed in June of year $t+1$. Panel A presents the average monthly returns in excess of the risk-free rate. Panels $B$ and $C$ present the three- and four-factor alphas, respectively, for the three sales growth groups. The last row reports the $p$-values for the difference portfolio's average returns, and three- and four-factor alphas, in panels A, B, and C, respectively. Excess returns, three-factor alphas and four-factor alphas are in percentages. ***, *** indicate significance at the 10,5 and 1 percent levels, respectively.

For each of these reported regressions, the values of the explanatory variables for individual stocks are matched with CRSP returns for the months from July of year $t$ to June of year $t+1$. In model 1 , we estimate a regression of monthly stock returns on the market share growth (MKTSHRG) and BETA, which is the post-ranking beta computed as in Fama and French (1992). The coefficient on market share growth $(M K T S H R G)$ is -0.00831 and highly 
Table 7

Market share growth regressions

\begin{tabular}{|c|c|c|c|c|c|}
\hline Variable & Model 1 & Model 2 & Model 3 & Model 4 & Model 5 \\
\hline Intercept & $0.0078 * * *$ & $0.0209 * * *$ & $0.0187 * * *$ & $0.0182 * * *$ & $0.0182 * * *$ \\
\hline$p$-value & $(0.00100)$ & $(<0.00001)$ & $(<0.00001)$ & $(<0.00001)$ & $(<0.00001)$ \\
\hline$M K T S H R G$ & $-0.0083 * * *$ & $-0.0068^{* * *}$ & $-0.0057 * * *$ & $-0.0056^{* * *}$ & $-0.0022 * * *$ \\
\hline$p$-value & $(<0.00001)$ & $(<0.00001)$ & $(<0.00001)$ & $(<0.00001)$ & $(0.00964)$ \\
\hline$B E T A$ & 0.0045 & 0.0003 & 0.0011 & 0.0007 & 0.0011 \\
\hline$p$-value & $(0.13193)$ & $(0.90790)$ & $(0.67149)$ & $(0.76395)$ & $(0.64435)$ \\
\hline$L N M E$ & \multirow[t]{2}{*}{-} & $-0.0016^{* * *}$ & $-0.0013 * * *$ & $-0.0014 * * *$ & $-0.0013 * * *$ \\
\hline$p$-value & & $(<0.00001)$ & $(0.00037)$ & $(0.00011)$ & $(0.00025)$ \\
\hline$L N B M$ & \multirow[t]{2}{*}{-} & \multirow[t]{2}{*}{-} & $0.0020 * * *$ & $0.0021 * * *$ & $0.0019 * * *$ \\
\hline$p$-value & & & $(0.00132)$ & $(0.00056)$ & $(0.00212)$ \\
\hline$C U M R E T$ & \multirow[t]{2}{*}{-} & \multirow[t]{2}{*}{-} & \multirow[t]{2}{*}{-} & $0.0043 * * *$ & $0.0041 * *$ \\
\hline$p$-value & & & & $(0.00707)$ & $(0.0102)$ \\
\hline$A T G R O W T H$ & \multirow[t]{2}{*}{-} & \multirow[t]{2}{*}{-} & \multirow[t]{2}{*}{-} & \multirow[t]{2}{*}{-} & $-0.0056 * * *$ \\
\hline$p$-value & & & & & $(<0.00001)$ \\
\hline Adj. $R^{2}$ & 0.0205 & 0.0310 & 0.0348 & 0.0419 & 0.0427 \\
\hline
\end{tabular}

This table presents the coefficients from Fama-Macbeth regressions of monthly stock returns on market share growth, beta, size, book-to-market, cumulative past returns and asset growth. Our sample of stocks includes all NYSE, AMEX and NASDAQ common stocks for the 1964-2012 period after excluding all financial stocks and firms with annual sales less than $\$ 5$ million. Market share growth, MKTSHRG, is as defined in Table 1. BETA is the postranking beta computed as in FF (1992). Natural logarithm of the firm size, $L N M E$, is as of June of year $t$. Book-to-market $(B E / M E)$ ratio is computed using market equity $M E$ as of December of year $t-1$. $B E$ is the book value of common equity plus balance-sheet deferred taxes. $B E$ is obtained for each firm's latest fiscal year ending in calendar year $t-1 . L N B M$ is natural logarithm of $B E / M E$. The cumulative past returns, CUMRET, for each stock, for each month $m$ are computed by cumulating their returns from $m-12$ to $m-2$ months. In the regressions, these values of the explanatory variables for individual stocks are matched with CRSP returns for the months from July of year $t$ to June of year $t+1$. ATGROWTH is the asset growth and is computed as $\left(T A_{i}-T A_{t-1}\right) / T A_{t}$, where $T A_{t}$ is the total assets of the firm at the end of the fiscal year $t$. The average coefficients are the time-series averages of the monthly regression coefficients for the 1964-2012 period. $p$-values, which are calculated using the Newey-West autocorrelation-adjusted standard errors, are presented in parenthesis. *, ${ }^{* *}$, *** indicate significance at the 10,5 and 1 percent levels, respectively.

significant. One standard deviation increase in market share growth leads to $\sim 3$ percent $(-0.00831 * 0.3 * 12)$ annual decrease in stock returns after controlling for systematic risk. ${ }^{6}$ In model 2 , we add another control variable, firm size, which has been widely reported to affect stock returns. $L N M E$ is defined as natural logarithm of the firm size as of June of year $t$. We report that in model 2 also, the coefficient on market share growth is negative $(-0.0068)$ and significant at one percent level. In model 3 , we add yet another control variable, 
namely, $\log$ of book-to-market, which has also been reported to affect stock returns. Book-to-market is the ratio of book value of equity to market value of equity. This ratio is computed using market equity $(M E)$ as of December of year $t-1$. Book equity $(B E)$ is the book value of common equity plus balancesheet deferred taxes. $B E$ is obtained for each firm's latest fiscal year ending in calendar year $t-1$. $L N B M$ is the natural logarithm of $B E / M E$. We report that the coefficient on market share growth (MKTSHRG) is still negative $(-0.00567)$ and statistically significant at one percent level of significance. Cumulative past returns (CUMRET) have also been reported to impact stock returns. In model 4 , we include cumulative past returns as another control variable. CUMRET, for each stock, for each month $m$, are computed by cumulating their returns from $m-12$ to $m-2$ months. Even after controlling for past cumulative returns, the coefficient on market share growth (MKTSHRG) is negative $(-0.00561)$ and statistically significant. One standard deviation increase in market share growth leads to more than 2 percent decrease in annual stock returns after controlling for systematic risk, size, book-to-market and past cumulative returns. Finally, asset growth has been reported to be an important determinant of stock returns (see Cooper et al., 2008). In model 5, as a robustness check, we also include asset growth in our regression analysis as an additional control variable. $A G$ is the asset growth and is computed as $\left(T A_{t}-T A_{t-1}\right) / T A_{t-1}$, where $T A_{t}$ is the total assets of the firm at the end of the fiscal year $t$. The coefficient on market share growth $(M K T S H R G)$ is negative $(-0.00219)$ and highly significant even though the magnitude of the coefficient decreases.

The results reported in Table 7 indicate that market share growth is an important explanatory variable of subsequent monthly stock returns. Market share growth is significant even after controlling for all other known factors, which are supposed to affect stock returns, including asset growth.

\subsection{Market share growth and stock returns - quarterly financial statements}

We extend our analysis using quarterly market share growth to explore any quarterly pattern in the relationship between market share growth and subsequent average excess monthly returns. Table 8 presents the average excess monthly returns and three- and four-factor alphas earned by portfolios based on quarterly market share growth for our sample of stocks for the 19642012 period. At the end of each quarter-end month $m$ (March, June, September and December of each year), we sort all stocks in our sample into deciles based on previous fiscal quarter's market share growth using quarterly financial statements. Quarterly market share growth is defined in the Section 2. Monthly equal-weighted stock returns for the ten portfolios and the difference portfolio that buys highest market share growth portfolio and sells short lowest market share growth portfolio (High-Low) are calculated for the following holding periods: $q+2, q+3, q+4, q+5, q+6, q+7, q+8, q+9$. These 
Table 8

Market share growth and stock returns using quarterly compustat data

\begin{tabular}{|c|c|c|c|c|c|c|c|c|}
\hline Qtrly.Mkt. share growth & $q+2$ & $q+3$ & $q+4$ & $q+5$ & $q+6$ & $q+7$ & $q+8$ & $q+9$ \\
\hline \multicolumn{9}{|l|}{ Panel A. Excess returns } \\
\hline Low & $0.61 *$ & $0.88^{* * *}$ & $1.06^{* * * *}$ & $1.16^{* * *}$ & $1.13 * * *$ & $1.08 * * *$ & $1.07 * * *$ & $104^{* * * *}$ \\
\hline High & $0.68^{* *}$ & 0.50 & 0.30 & 0.26 & 0.35 & 0.40 & 0.43 & $0.54^{*}$ \\
\hline High-Low & 0.07 & $-038^{* * *}$ & $-0.76^{* * *}$ & $-0.90^{* * *}$ & $-0.78 * * *$ & $-0.68 * * *$ & $-0.64 * * *$ & $-0.50^{* * *}$ \\
\hline$p$-value & 0.56938 & 0.00251 & $<0.00001$ & $<0.00001$ & $<0.00001$ & $<0.00001$ & $<0.00001$ & $<0.00001$ \\
\hline \multicolumn{9}{|c|}{ Panel B. Three-factor alphas } \\
\hline Low & $-0.25^{*}$ & 0.00 & 0.20 & $0.32 * *$ & $0.27 * *$ & $0.26^{* *}$ & $0.28 * *$ & $0.28^{* *}$ \\
\hline High & -0.04 & $-0.22 * *$ & $-0.43^{* * *}$ & $-0.47 * * *$ & $-0.42 * * *$ & $-0.36^{* * *}$ & $-0.31 * * *$ & $-0.22 *$ \\
\hline High-Low & $0.21^{*}$ & $-0.22^{*}$ & $-0.64^{* * *}$ & $-0.79^{* * *}$ & $-0.69 * * *$ & $-0.62 * * *$ & $-0.59^{* * *}$ & $-0.50^{* * *}$ \\
\hline$p$-value & 0.07298 & 0.05531 & $<0.00001$ & $<0.00001$ & $<0.00001$ & $<0.00001$ & $<0.00001$ & $<0.00001$ \\
\hline \multicolumn{9}{|l|}{ Panel C. Four-factor alphas } \\
\hline Low & 0.05 & $0.30^{* *}$ & $0.47^{* * *}$ & $0.56^{* * * *}$ & $0.50^{* * *}$ & $0.45^{* * *} *$ & $0.45^{* * * *}$ & $044 * * *$ \\
\hline High & 0.10 & -0.02 & $-0.18^{* *}$ & $-0.20^{* *}$ & -0.12 & -0.07 & -0.01 & 0.04 \\
\hline High-Low & 0.05 & $-0.33^{* * *}$ & $-0.65^{* * *}$ & $-0.76^{* * *}$ & $-0.62^{* * *}$ & $-0.52 * * *$ & $-0.46^{* * *}$ & $-0.40^{* * *}$ \\
\hline
\end{tabular}

This table presents the average monthly returns and three- and four-factor alphas earned by portfolios based on quarterly market share growth constructed with all NYSE, AMEX and NASDAQ common stocks for the 19642012 period after excluding all financial stocks and firms with annual sales less than $\$ 5$ million. At the end of each quarter-end month $m$ (March. June. September and December of each year), we sort all stocks in our sample into deciles based on previous fiscal quarter market share growth using quarterly financial statements. Quarterly market share growth is defined as

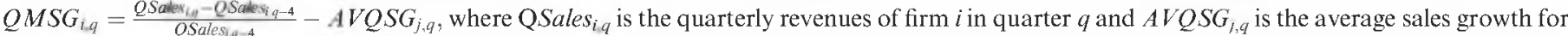
ind ustry $j$ in quarter $q$. Monthly equal-weighted stock returns for the difference portfolio that buys highest market share growth portfolio and sells short lowest market share growth portfolio (High-Low) are calculated for the following holding periods: $m+4$ to $m+6$ or $q+2, m+7$ to $m+9$ or $q+3$, $m+10$ to $m+12$ or $q+4, m+13$ to $m+15$ or $q+5, m+16$ to $m+18$ or $q+6, m+19$ to $m+21$ or $q+7, m+22$ to $m+24$ or $q+8, m+25$ to $m+28$ or $q+9$. These portfolios are rebalanced every quarter. Panel A presents the average monthly returns in excess of the risk-free rate. Panels B and $\mathrm{C}$ present the three- and four-factor alphas, respectively, for the eight different holding periods with respect to the formation month $m$. The last row reports the $p$-values for the difference portfolio's average returns, and three- and four-factor alphas, in panels A, B and C, respectively. Excess returns, three-factor alphas and four-factor alphas are in percentages. ${ }^{*}, * * * *$ indicate significance at the 10,5 and 1 percent levels, respectively. 
portfolios are rebalanced every quarter. Panel A presents the average monthly returns for the lowest and highest market share growth portfolios as well as for the difference portfolio.

We identify a distinct quarterly pattern in the relationship between market share growth and the subsequent average excess monthly returns. For the second quarter after formation, that is $q+2$, the difference portfolio's average monthly return is positive ( 0.07 percent), but statistically insignificant. ${ }^{7}$ For the third quarter after formation, that is $q+3$, we observe that the difference portfolio earns a negative and statistically significant monthly return of -0.38 percent. For the fourth quarter after formation, $q+4$, the difference portfolio's return becomes more negative $(-0.76$ percent $)$. For the subsequent fifth quarter after formation, $q+5$, the difference portfolio reports a negative -0.90 percent average excess monthly returns, which is highly significant. We note that the average excess monthly returns of difference portfolio (HighLow) becomes more negative and significant as the holding period changes from one quarter to the next quarter with the maximum negative returns being reported for the holding period $q+5$ (fifth quarter after formation). Beyond the holding period $q+5$, the average returns for the difference portfolio decreases in magnitude consistently.

Panels B and C present the three- and four-factor alphas of difference portfolio, respectively, for the 8 different holding periods with respect to the formation month $m$. Again, we find a pattern which is similar to that of the excess raw returns reported in panel $\mathrm{A}$.

Overall, the results in Table 8 suggest that the negative relationship between market share growth and subsequent stock returns is driven by the stock returns from the third quarter onwards after formation with the highest negative relationship being observed for the stock returns for the fifth quarter. Similar patterns are observed for the negative relationship between the market share growth and the subsequent three/four-factor alphas.

\section{Potential explanation}

In this section, we propose a potential explanation for the negative relationship between market share growth and subsequent stock returns. We argue that this negative relationship could be explained by the mispricing caused by overreaction of investors, which is in the same vein as Cooper et al. (2008) and Skinner and Sloan (2002). Investors overreact to good news when firms experience high market share growth accompanied by good operating performance. Investors overvalue these firms as they expect that this superior performance will continue in the future. However, these firms cannot sustain their superior performance. As the operating performances of these firms deteriorate over the subsequent 
periods, investors are surprised by these negative news realising that their expectations about these firms were incorrect. This yields poor stock market performance for these firms. Similarly, investors overreact to bad news when firms report low market share growth coupled with bad operating performance. The investors have expectation that these firms' poor operating performance will continue in the future. Improving operating performances of these firms surprise investors resulting in good stock market performance in the subsequent periods. To test our hypothesis, we first examine whether there is any evidence of low (high) profitability for the low (high) market share growth firms in the formation quarter followed by improvement (deterioration) in the subsequent quarters. We then explore whether the low and high market share growth firms experience earning surprise and whether there is any reversal in the unexpected earnings for the low and high market share growth firms in the subsequent quarters. We finally investigate whether investors are surprised with these changes in profit margin by comparing the returns around the announcement days with the returns excluding announcement days in the subsequent quarters.

\subsection{Market share growth and operating performance}

We examine the profitability of the firms with low and high market share growth firms for the formation quarter (during which the quarterly market share growth is measured) and the subsequent quarters. To this end, at the end of each quarter $q$ during the 1964-2012 period, we sort all stocks in our sample into deciles based on previous fiscal quarter's market share growth as in Section 3.4. We calculate the time-series mean of the median quarterly operating profit margin and net profit margin for these decile portfolios for quarters $q$ to $q+12$. We plot these mean values for operating profit margin and net profit margin in panels A and B of Figure 1, respectively, for the low (Decile 1) and high (Decile 10) quarterly market share growth deciles. We define operating profit margin as operating income before depreciation (Compustat data item OIBDPQ) divided by contemporaneous quarter net sales (Compustat data item SALEQ) and net profit margin as income before extraordinary items (Compustat data item IBQ) divided by contemporaneous quarter net sales.

As can be seen from these two panels, consistent with the overreaction hypothesis, during the formation quarter, firms with high market share growth have significantly higher profit margins than the firms with low market share growth. However, these differences in profit margins decrease in subsequent quarters as the profit margins for firms with low (high) market share growth improve (deteriorate).

\subsection{Market share growth and earnings surprises}

In this subsection, we examine whether the firms with low and high market share growth experience earnings surprises in the formation quarter and how 
these earnings surprises change over the subsequent quarters. At the end of each quarter $q$ for the 1964-2012 period, we sort all stocks in our sample into deciles based on previous fiscal quarter's market share growth as defined in Section 3.4. We then compute average standardised unexpected earnings, for the decile portfolios and the difference portfolio that buys highest market share growth portfolio and sells short lowest market share growth portfolio (High-Low) for quarters $q$ to $q+6$. We then compute the time-series average of these standardised unexpected earnings for each of these portfolios over our sample period. Following Chordia and Shivakumar (2006), we define standardised unexpected earnings ( $S U E$ ) as,

$$
S U E_{i, q}=\left(E_{i, q}-E_{i, q-4}\right) / S t d_{i, q},
$$

where $E_{i, q}$ is the earnings for firm $i$ in quarter $q$, and $s t d_{i, q}$ is the standard deviation of the $\left(E_{i . q}-E_{i q-4}\right)$ over the prior eight quarters. We present the results of this analysis in Panel A of Table 9. We report in this panel that for the first two quarters after the market share growth is calculated, the low (high) market share growth portfolio experiences negative (positive) SUE with the difference (HighLow) portfolio experiencing a positive and statistically significant SUE. However, in the third quarter after the formation quarter, we observe a positive (negative) SUE for the low (high) market share growth portfolio. ${ }^{8}$ Positive SUE has been widely reported to be associated with subsequent higher monthly stock returns (see Chan et al., 1999). We document in Table 8 that low (high) portfolio based on market share growth reports higher (lower) stock returns in the third quarter after formation. Similar patterns are observed for the fourth, fifth and sixth quarters after formation. We report that in fourth, fifth and sixth quarters after formation, the low (high) portfolio based on market share growth experiences positive (negative) SUE. As a result, the low (high) market sharebased portfolio reports higher (lower) stock returns in the fourth, fifth and sixth quarters, respectively, as reported in the previous table, Table 8.

In Panel B of Table 9, we report the earnings surprises as the difference between actual earnings and the consensus forecast of $\mathrm{I} / \mathrm{B} / \mathrm{E} / \mathrm{S}$ analysts scaled by the absolute value of the consensus. The results presented in this panel indicate that there are more negative surprises than positive surprises and that the absolute value of negative surprises is larger than that of positive surprises. This result is in line with the previously documented average overoptimism in sell-side analysts' earnings forecasts (see Brown, 1998; Abarbanell and Lehavy, 2003; Livant and Mendenhall, 2006; Scherbina, 2008). This panel also shows that for the formation quarter and next quarter after portfolio formation ( $q$ and $q+1$ ), high (low) portfolio based on market share growth experiences positive (negative) earnings surprises. Beyond the initial two quarters, high 
Table 9

Market share growth and average SUEs in subsequent quarters

\begin{tabular}{|c|c|c|c|c|c|c|c|}
\hline Quarterly Mkt. share growth & $q$ & $q+1$ & $q+2$ & $q+3$ & $q+4$ & $q+5$ & $q+6$ \\
\hline \multicolumn{8}{|c|}{ Panel A. SUEs based on past earnings } \\
\hline Low & -35.78 & -17.44 & -4.29 & 13.39 & 7.14 & 6.74 & 6.98 \\
\hline High & 28.59 & 13.06 & 0.40 & -14.33 & -11.64 & -10.37 & -9.41 \\
\hline High-Low & 65.84 & 30.50 & 3.89 & -28.11 & -18.78 & -17.50 & -16.39 \\
\hline$p$-value & $<0.00001$ & $<0.00001$ & 0.06565 & $<0.00001$ & $<0.00001$ & $<0.00001$ & $<0.00001$ \\
\hline \multicolumn{8}{|c|}{ Panel B. SUEs based on analysts' earnings forecasts } \\
\hline Low & -44.90 & -46.24 & -31.57 & -25.78 & -24.44 & -20.43 & -20.56 \\
\hline High & 0.44 & 2.48 & -3.63 & -6.85 & -11.12 & -13.63 & -15.12 \\
\hline High-Low & 45.34 & 48.73 & 27.94 & 18.93 & 13.32 & 6.79 & 5.44 \\
\hline$p$-value & $<0.00001$ & $<0.00001$ & $<0.00001$ & $<0.00001$ & $<0.00001$ & 0.0060 & 0.0629 \\
\hline
\end{tabular}

This table presents the average SUEs for the portfolios constructed based on quarterly market share growth of our sample of stocks for the 1964 2012 period. At the end of each quarter $q$, we sort all stocks in our sample into deciles based on fiscal quarter market share growth using quarterly financial statements. Quarterly market share growth is as defined in Table 8 . We then compute average standardised unexpected earnings, for the low (Decile 1) and high (Decile 10) portfolios and the difference portfolio that buys highest market share growth portfolio and sells short lowest market share growth portfolio (High-Low) for quarters $q$ to $q+6$. We compute the time-series average of these standardised unexpected earnings for each of these portfolios over our sample period. In Panel A, following Chordia and Shivakumar (2006) we define standardised unexpected earnings $(S U E)$ as, $S U E_{i, q}=\left(E_{i, q}-E_{i, q-4}\right) / S t d_{i, q}$, where $E_{i, q}$ is the earnings for firm $i$ in quarter $q$, and $s t d_{i, q}$ is the standard deviation of the $\left(E_{i, q}-E_{i,}\right.$ $q-4$ ) over the prior eight quarters. In Panel B, we define earnings surprise as the difference between realised earnings and consensus forecast of the I/ B/E/S analysts' forecasts scaled by the absolute value of the consensus. The sample period for Panel B starts from 1984 as I/B/E/S data is available after 1984. The last rows in each panel report the p-values for the difference portfolio's average SUEs. SUES are in percentages. 
market share growth portfolio experiences negative earnings surprises. On the other hand. low market share growth portfolio experiences less negative earnings surprises over time.

In a nutshell, the results in Table 9 suggest that firms with low (high) market share growth experience negative (positive) earnings surprises in the formation quarter. In the subsequent quarters, these earnings surprises increase (decreases) for firms with low (high) market share growth.

\subsection{Stock returns around announcement days and other days}

In order to explore whether the above-documented change in the profitability of the firms with low and high market share growth is expected by the investors, we examine the average daily returns to these firms around the earnings announcement days and during the days excluding earnings announcements in the formation and subsequent quarters. At the end of each quarter $q$, we sort all stocks in our sample into deciles based on quarterly market share growth using quarterly financial statements as in Section 3.4. We then calculate the average daily returns around earnings announcement days (day -1 to day +1 ) for these portfolios in quarters $q$ to $q+6 .{ }^{9} \mathrm{We}$ also compute the difference in the average daily earnings announcement days returns between firms with high and low market share growth. In Panel A of Table 10, we report these results. Similarly, we compute the average daily returns excluding the earnings announcement days in quarters $q$ to $q$ +6 for same portfolios and report the results in Panel B of Table 10.

In the formation quarter, quarter $q$. the average daily announcement day returns for low (high) market share growth firms is negative (positive). Moreover, the difference in average daily earnings announcement day returns between low and high market share growth firms is 0.954 percent, significant at the 1 percent level. These findings indicate that investors react negatively (positively) to the earnings announcements of low (high) market share growth firms. In the subsequent quarters, earnings announcement day returns for the low (high) market share growth firms increases (decreases). The difference in average daily earnings announcement day returns between low and high market share growth firms becomes negative by quarter $q+2$ and reaches its lowest level of -0.361 by quarter $q+4$.

In Panel $\mathrm{B}$, we report the average daily returns excluding the earnings announcement days. The average daily stock returns of low market share growth firms in the formation quarter excluding the earnings announcements day is 0.083 percent, which is in stark contrast with the corresponding average daily earnings announcement day returns of -0.405 percent. Similarly, the average daily stock returns of high market share growth firms in the formation period excluding earnings announcement days is as low as 0.096 percent, 
Table 10

Average announcement day stock returns and average stock returns excluding announcement days

\begin{tabular}{|c|c|c|c|c|c|c|c|}
\hline Quarterly Mkt. share growth & $q$ & $q+1$ & $q+2$ & $q+3$ & $q+4$ & $q+5$ & $q+6$ \\
\hline \multicolumn{8}{|c|}{ Panel A. Average daily announcement day stock returns } \\
\hline High & $0.550 * * *$ & $0.144 * * *$ & $0.067^{*}$ & 0.008 & $-0.077 * *$ & -0.014 & 0.013 \\
\hline High-Low & $0.954 * * *$ & $0,119 * * *$ & $-0.060 * *$ & $-0.182 * * *$ & $-0.361 * * *$ & $-0.274 * * *$ & $-0.249 * * *$ \\
\hline$p$-value & $<0.00001$ & 0.00004 & 0.02869 & $<0.00001$ & $<0.00001$ & $<0.00001$ & $<0.00001$ \\
\hline \multicolumn{8}{|c|}{ Panel B. Average daily stock returns excluding announcement days } \\
\hline Low & $0.083 * * *$ & $0.111 * * *$ & $0.117 * * *$ & $0.122 * * *$ & $0.129 * * *$ & $0.125 * * *$ & $0.123 * * *$ \\
\hline High & $0.096 * * *$ & $0.064 * * *$ & $0.059 * * *$ & $0.060 * * *$ & $0.064 * * *$ & $0.069 * * *$ & $0.074 * * *$ \\
\hline High-Low & $0.013^{*}$ & $-0.048 * * *$ & $-0.058 * * *$ & $-0.062 * * *$ & $-0.065 * * *$ & $-0.056^{* * *}$ & $-0.050 * * *$ \\
\hline$p$-value & 0.09623 & $<0.00001$ & $<0.00001$ & $<0.00001$ & $<0.00001$ & $<0.00001$ & $<0.00001$ \\
\hline
\end{tabular}

Panel A presents the average daily returns around the earnings announcement days (announcement day -1 to announcement day +1 ) for the 1971-2012 period. At the end of each quarter $q$, we sort all stocks in our sample into deciles based on quarterly market share growth using quarterly financial statements. Quarterly market share growth is defined as in Table 8. We then calculate the average daily returns around earnings announcement days for quarter $q$ to $q+6$. We also compute the difference between the average daily earnings announcement days returns of high and low market share growth firms. Earning announcement dates (rdq) are obtained from Compustat. Panel B of this table presents the average daily returns excluding the earnings announcement days for the quarters $q$ to $q+6$ for same portfolios. Returns are in percentages. ${ }^{*}, * *, * *$ indicate significance at the 10,5 and 1 percent levels, respectively. 
compared to the corresponding average earnings announcement day return of 0.550 percent. These results suggest that during the formation quarter, the investors are negatively (positively) surprised by earnings announcements for the low (high) market share firms. Moreover, we also observe that the average daily returns excluding the earnings announcement days in subsequent quarters (beyond $q+2$ ) for low (high) market share growth firms are higher (lower) than that for announcement days. For example, in quarter $q+4$, the average daily returns for earnings announcement days for the low (high) market share growth firms is 0.284 percent $(-0.077$ percent). The average daily returns excluding the earnings announcement days for low (high) market share growth firms is 0.129 percent $(0.064$ percent). Furthermore, the difference in the average daily returns between low and high market share growth firms for the days excluding earnings announcement days is only -0.065 percent, approximately one-sixth of that for the earnings announcement days ( -0.361 percent).

These observed differences between average daily returns around earnings announcement days and other days in the subsequent quarters indicate that investors are surprised by the earnings news of low and high market share growth firms.

In sum, our findings are in support of our explanation. We report that the low (high) market share growth firms experience poor (good) operating performance during the formation quarter. We show that investors react negatively (positively) to the initial poor (good) performance of low (high) market share growth firms. However, in the subsequent quarters, the low (high) market share firms report improvement (deterioration) in operating performance. We also find evidence of reversals in SUEs, in opposite directions, for the low and high market share firms. We finally document evidence indicating that investors are surprised by these reversals in operating performances.

\section{Robustness tests}

In this section, we perform two robustness analyses. First, we show that our measure of market share growth is different from the sales growth measure that is used in LSV and provides a substantial improvement. Second, we replicate our main results using value-weighted portfolio returns and show that our inferences remain the same.

\subsection{Sales growth versus market share growth}

Lakonishok et al. (1994) investigate value and glamour strategy returns over April 1968 to April 1990 period. They sort stocks into deciles based on several measures like the ratio of book value of equity to market value of equity $(B / M)$, the ratio of cash flow to market value of equity $(\mathrm{C} / \mathrm{P})$, the ratio of earnings to market value of equity $(\mathrm{E} / \mathrm{P})$ and the 5 -year average sales growth $(\mathrm{G} / \mathrm{S})$ to identify value and glamour stocks. The decile portfolios with the lowest 
(highest) $\mathrm{B} / \mathrm{M}$ or $\mathrm{C} / \mathrm{P}$ or $\mathrm{E} / \mathrm{P}$ or highest (lowest) $\mathrm{G} / \mathrm{S}$ are identified as glamour (value) portfolios. They report that value portfolios earn higher subsequent returns compared to the glamour portfolios. Their findings are not consistent with a risk-based explanation for this phenomenon.

Our measure of market share growth is mechanically related to sales growth. It is possible that our results are essentially reflecting the findings of LSV (1994). In order to examine whether our market share growth measure provides a substantial improvement over sales growth measure used in LSV, we perform two different analyses.

In our first analysis, for each year $t$, we categorise stocks in our sample with end-of-June sales growth below 30th percentile as low sales growth, between 30 th and 70th percentiles as intermediate sales growth, and above 70th percentile as high sales growth stocks. Sales growth is defined as $S G_{i, t}=$ Sales $_{i,}$ $t_{t}-$ Sales $_{i, t-1}$, where Sales $_{i, t}$ is the total revenues of firm $i$ in fiscal year $t$. We then separately sort the stocks in these three sales growth groups into deciles based on previous fiscal year's market share growth. As before, these portfolios are equal-weighted and reformed in June of each year. In Table 11, we report the average monthly excess returns and three- and four-factor alphas earned by the low (Decile 1) and high (Decile 10) market share growth portfolios and difference portfolio for the three sales growth groups during 1964-2012 period. Panel A presents the average monthly excess returns. Consistent with the previous results, we report a negative association between market share growth at year $t$ and average monthly excess returns in the subsequent year for all three sales growth groups, with the difference portfolio (High-Low)'s average monthly returns being negative and statistically significant. Panel B and C present the three- and four-factor alphas, respectively, for the three sales growth groups. We document a negative relationship between the three/fourfactor alphas and market share growth for all the three sales growth groups. These results suggest that the negative association between market share growth and subsequent stock returns is not driven by sales growth because the negative association prevails in all the three sales growth groups.

For our second analysis, we sort all stocks independently into quintiles based on previous fiscal year market share growth and sales growth. In panel A of Table 12, we report the average monthly equal-weighted stock returns for the low (quintile 1) and high (quintile 5) quintile portfolios and the difference portfolio that buys highest market share growth portfolio and sells short lowest market share growth portfolio (High-Low). These returns are calculated from July of year $t$ to June of year $t+1$. These portfolios are reformed in June of year $t+1$. First (second) row of the first column presents the average monthly returns to the stocks that are in quintile 1 (5) based on both measures, sales growth and market share growth. First (second) row of the second column presents the average monthly returns to the stocks that are in quintile 1 (5) based on market share growth but not quintile 1 (5) based on sales growth measure. First (second) row of the third column presents the average monthly 
Table 11

Market share growth and sales growth - dependent sort

\begin{tabular}{lccc}
\hline Mkt. share growth & Low sales growth & Inter. sales growth & High sales growth \\
\hline Panel A. Excess returns & & & \\
\hline Low & $1.297 * * *$ & $1.027 * * *$ & $0.814^{* * *}$ \\
High & $0.835^{* * *}$ & $0.881^{* * *}$ & 0.087 \\
High-Low & $-0.461 * *$ & -0.146 & $-0.727 * * *$ \\
-value & 0.03184 & 0.18900 & $<0.00001$ \\
\hline
\end{tabular}

Panel B. Three-factor alphas

\begin{tabular}{lccc}
\hline Low & $0.379 * *$ & $0.349 * * *$ & 0.180 \\
High & 0.013 & $0.135^{*}$ & $-0.661 * * *$ \\
High-Low & $-0.366^{* *}$ & $-0.213^{*}$ & $-0.841^{* * *}$ \\
$p$-value & 0.03669 & 0.05057 & $<0.00001$ \\
\hline
\end{tabular}

Panel C. Four-factor alphas

\begin{tabular}{lccc}
\hline Low & $0.583^{* * *}$ & $0.520^{* * *}$ & $0.346^{* * *}$ \\
High & $0.181^{*}$ & $0.264^{* * *}$ & -0.226 \\
High-Low & $-0.402^{* *}$ & $-0.256^{* *}$ & $-0.572^{* * *}$ \\
$p$-value & 0.02480 & 0.02133 & 0.00005 \\
\hline
\end{tabular}

This table presents the average monthly returns and three- and four-factor alphas earned by portfolios based on market share growth constructed for low, intermediate and high sales growth stocks during 1964-2012. In June of year $t$, we categorise stocks in our sample with previous fiscal year sales growth below 30 th percentile as low, between 30 th and 70 th percentiles as intermediate, and above 70th percentile as high sales growth stocks. Sales growth is defined as $S G_{i, t}=\left(\right.$ Sales $_{i, t}-$ Sales $\left._{i, t-1}\right) /$ Sales $_{i, t-1}$, where Sales $_{i, t}$ is the total revenues of firm $i$ in fiscal year $t$. We then separately sort the stocks in these three sales growth groups into deciles based on previous fiscal year market share growth. Market share growth is as defined in Table 1. Monthly equal-weighted stock returns for the bottom (low) and top (high) deciles and the difference portfolio that buys highest market share growth portfolio and sells short lowest market share growth portfolio (High-Low) are calculated from July of year $t$ to June of year $t+1$, for each sales growth group. These portfolios are reformed in June of year $t+1$. Panel A presents the average monthly returns in excess of the risk-free rate. Panels $B$ and $C$ present the three- and four-factor alphas, respectively, for the three sales growth groups. The last row reports the $p$ values for the difference portfolio's average returns, and three- and four-factor alphas, in panels A, B and C, respectively. Excess returns, three-factor alphas and four-factor alphas are in percentages. $* * *, * * *$ indicate significance at the 10,5 and 1 percent levels, respectively.

returns to the stocks that are in quintile 1 (5) based on sales growth but not quintile 1 (5) based on market share growth measure. Third row is the difference between the average returns for the respective quintile 5 and quintile 1 stocks for all these three columns. Panels B and C presents the three- and four-factor alphas and the corresponding $p$-values, respectively, for the same portfolios. 
Table 12

Market share growth and sales growth - independent sort

\begin{tabular}{llll}
\hline Mkt. share growth & Both & Only Mkt. Shr. G. & Only SG \\
\hline
\end{tabular}

Panel A. Excess returns

\begin{tabular}{lccc}
\hline Low (quintile 1) & $1.229 * * *$ & $1.032 * * *$ & $0.950 * * *$ \\
High (quintile 5) & $0.526 * * *$ & $0.667^{* * *}$ & $0.696 * * *$ \\
High-Low & $-0.702^{* * *}$ & $-0.365^{* * *}$ & -0.254 \\
$p$-value & $<0.00001$ & 0.00122 & 0.17165 \\
\hline
\end{tabular}

Panel B. Three-factor alphas

\begin{tabular}{lccc}
\hline Low (quintile 1) & $0.349^{* * *}$ & $0.318^{* * *}$ & 0.033 \\
High (quintile 5) & $-0.234^{* *}$ & -0.139 & 0.012 \\
High-Low & $-0.583^{* * *}$ & $-0.457^{* * *}$ & -0.021 \\
$p$-value & $<0.00001$ & 0.00006 & 0.89165 \\
\hline
\end{tabular}

Panel C. Four-factor alphas

\begin{tabular}{lccc}
\hline Low (quintile 1) & $0.557^{* * *}$ & $0.497^{* * *}$ & $0.209^{*}$ \\
High (quintile 5) & 0.027 & 0.028 & $0.243^{*}$ \\
High-Low & $-0.530^{* * *}$ & $-0.469^{* * *}$ & 0.033 \\
$p$-value & $<0.00001$ & 0.00006 & 0.83305 \\
\hline
\end{tabular}

This table presents the average monthly returns and three- and four-factor alphas earned by portfolios based on market share growth and sales growth constructed with all NYSE, AMEX and NASDAQ common stocks for the 1964-2012 period after excluding all financial stocks and firms with annual sales less than $\$ 5$ million. In June of year $t$, we sort all stocks independently into quintiles based on previous fiscal year market share growth and sales growth. Market share growth is defined as described in Table 1. Sales growth is defined as $S G_{i, t}=$ Sales $_{i, r}-$ Sales $_{i}$ $t_{t-1}$, where Sales $_{i, i}$ is the total revenues of firm $i$ in fiscal year $t$. Panel A presents the average monthly equal-weighted stock returns for the bottom (low) and top (high) quintile portfolios and the difference portfolio that buys highest market share growth portfolio and sells short lowest market share growth portfolio (High-Low). These returns are calculated from July of year $t$ to June of year $t+1$. These portfolios are reformed in June of year $t+1$. First (second) row of the first column presents the average monthly returns to the stocks that are in quintile 1 (5) based on both measures. First (second) row of the second column presents the average monthly returns to the stocks that are in quintile 1 (5) based on market share growth but not quintile 1 (5) based on sales growth measure. First (second) row of the third column presents the average monthly returns to the stocks that are in quintile 1 (5) based on sales growth but not quintile 1 (5) based on market share growth measure. Third row is the difference between the average returns for the respective quintile 5 and quintile 1 stocks for all these three columns. Panels B and C presents the three- and four-factor alphas and the corresponding $p$-values, respectively, for the same portfolios. ${ }^{*}, * * * *$ indicate significance at the 10,5 and 1 percent levels, respectively.

We note that when the stocks are sorted in quintile 1 (5) based on market share growth but not sorted in quintile 1 (5) based on sales growth measure (column 2 of Table 12), the difference portfolio generates negative and statistically significant 
returns and three- and four-factor alphas are also negative and statistically significant. When the stocks are sorted in quintiles 1 (5) based on both market share growth and sales growth (column 1 of Table 12), the difference portfolio earns negative statistically significant returns with negative significant three/fourfactor alphas. But when the stocks are sorted into quintile 1 (5) based solely on sales growth (column 3 ), the difference portfolio fails to generate any significant returns with the three/four-factor alphas also being statistically insignificant. We can infer from these results that the negative returns earned by the difference portfolio are driven by the returns of the stocks sorted based on market share growth and not by those stocks sorted by sales growth.

These results in Table 12 coupled with the results tabulated in Table 11 suggest that the negative association between market share growth and subsequent stock market reaction is not subsumed by sales growth. This leads us to conclude that our measure is a substantial improvement over the sales growth measure of LSV.

\subsection{Value-weighted returns}

We report equal-weighted returns in our portfolio analyses similar to numerous studies in the existing literature (e.g. Jegadeesh and Titman, 1993). A potential concern can be that our results are driven by small stocks and this market share growth effect on stock returns is a small stock phenomenon. In order to address this concern in Section 3.2, we show that market share growth affects subsequent stock returns for all three size groups. However, our findings in that analysis also indicate that this effect loses its strength as the firm size increases.

In this subsection, we address this concern by replicating our main analysis using the value-weighted portfolio returns following the methodology used in Bali et al. (2011). Our inferences remain the same for this analysis. ${ }^{10}$

We sort all stocks in our sample into tertiles based on their market capitalisation. In each size group, we then sort the stocks into deciles based on previous fiscal year market share growth. We calculate the monthly valueweighted stock returns for the thirty ( 3 size $\times 10$ market share growth) portfolios from July of year $t$ to June of year $t+1$. We then compute the equalweighted average returns for each market share growth portfolios across three size groups. These portfolios are reformed in June of year $t+1$. In panel A of Table 13, we report the average monthly returns in excess of the risk-free rate for the low (Decile 1) and high (Decile 10) market share growth portfolios and the difference portfolio that buys highest market share growth portfolio and sells short lowest market share growth portfolio (High-Low). In panels B and $\mathrm{C}$, we report the three- and four-factor alphas, respectively. The last row 
Table 13

Market share growth and subsequent stock returns - value weighted

\begin{tabular}{lcccc}
\hline Mkt. share growth & $1964-2012$ & $1964-1979$ & $1980-1995$ & $1996-2012$ \\
\hline Panel A. Excess returns & & & & \\
\hline Low & $0.841^{* * *}$ & $0.981^{* *}$ & 0.523 & $1.012^{* *}$ \\
High & 0.465 & 0.575 & 0.309 & 0.513 \\
High-Low & $-0.375^{* * *}$ & $-0.406^{* *}$ & -0.214 & $-0.499^{* * *}$ \\
$p$-value & 0.00016 & 0.01650 & 0.15981 & 0.00917 \\
\hline
\end{tabular}

Panel B. Three-factor alphas

\begin{tabular}{lcccr}
\hline Low & 0.126 & $0.258^{*}$ & -0.224 & \multicolumn{1}{c}{0.289} \\
High & $-0.194^{* *}$ & -0.064 & $-0.347^{* * *}$ & -0.165 \\
High-Low & $-0.320^{* * *}$ & $-0.322^{* *}$ & -0.123 & $-0.454^{* *}$ \\
$p$-value & 0.00051 & 0.03334 & 0.38137 & 0.01258 \\
\hline
\end{tabular}

Panel C. Four-factor alphas

\begin{tabular}{lcccr}
\hline Low & 0.159 & 0.216 & -0.233 & 0.329 \\
High & -0.119 & -0.059 & $-0.300^{* *}$ & -0.093 \\
High-Low & $-0.278^{* * *}$ & $-0.274^{*}$ & -0.067 & $-0.423^{* *}$ \\
$p$-value & 0.00295 & 0.08112 & 0.64237 & 0.02071 \\
\hline
\end{tabular}

This table presents the value-weighted average monthly returns and three- and four-factor alphas earned by portfolios based on market share growth constructed with all NYSE, AMEX and NASDAQ common stocks for the 1964-2012 period and for the three subperiods after excluding all financial stocks and firms with annual sales less than $\$ 5$ million. In June of year $t$, we sort all stocks in our sample into tertiles based on their market capitalisation. In each size group, we then sort the stocks into deciles based on previous fiscal year market share growth. Market share growth is defined as in Table 1. We calculate the monthly valueweighted stock returns for the thirty $(3$ size $\times 10$ market share growth) portfolios from July of year $t$ to June of year $t+1$. We then compute the equal-weighted average returns for each market share growth portfolios across three size groups. These portfolios are reformed in June of year $t+1$. Panel A presents the average monthly returns in excess of the risk-free rate for the bottom (low) and top (high) deciles and the difference portfolio that buys highest market share growth portfolio and sells short lowest market share growth portfolio (HighLow). Panel B and C present the three- and four-factor alphas, respectively. The last row reports the $p$-values for the difference portfolio's average returns, and three- and four-factor alphas, in panels A, B and C, respectively. Excess returns, three-factor alphas and four-factor alphas are in percentages. *.*.*** indicate significance at the 10,5 and 1 percent levels, respectively.

reports the $p$-values for the difference portfolio's average returns, and threeand four-factor alphas, in panels $A, B$ and $C$, respectively.

As documented in the second column, for the time period of 1964-2012, the difference portfolio generates negative and statistically significant subsequent 
excess returns, and three- and four-factor alphas. We divide the samples into three time periods, namely 1964-1979, 1980-1995 and 1996-2012 and report the results in columns three, four and five of Table 13, respectively. For all the three time periods, we report a negative association between market share growth and subsequent stock returns, three- and four-factor alphas, suggesting that our results are not driven by any particular time period. More importantly, the results in Table 13 indicate that we can replicate the results reported in Tables 1 and 2 using value-weighted returns. Hence, we can infer that our results are robust to value-weighting.

\section{Conclusion}

We document a negative association between market share growth and subsequent stock returns. Employing bivariate portfolio analyses, we report that this negative association is robust to firm size, book-to-market, past cumulative returns and asset growth and it prevails over various time periods. We also perform multivariate analysis and report that market share growth retains its explanatory power in explaining subsequent stock returns even after the inclusion of various control variables, which are known to affect stock returns.

We extend our analysis using quarterly financial statements. We observe a quarterly pattern in the relationship between market share growth and the subsequent average monthly returns. Our results suggest that the negative relationship between market share growth and subsequent stock returns is driven by the stock returns from the third quarter onwards after formation period with the highest negative relationship being observed for the stock returns for the fifth quarter after the formation period. These results suggest that increase in market share of a firm is inimical to the shareholders of the firm in the subsequent periods.

The negative relationship between market share growth and stock returns can be explained by investor overreaction and subsequent correction. Initially, the investors have irrationally high optimistic (pessimistic) expectation of the high (low) market share growth firms. These high (low) market share firms are reported to have good (bad) operating performance and highly positive (negative) SUEs in the quarter in which market share growth is measured. The high (low) market share growth firms experience deterioration (improvement) of operating performance and reduction (improvement) in SUEs. Investors are surprised by the bad (good) news about the high (low) market share firms leading to correction in investors' expectations. This correction in investors' expectations results in reduction (improvement) of subsequent stock market performance for high (low) market share firms.

Our results are not subsumed by the asset growth measure of Cooper et al. (2008) who report that asset growth explains subsequent stock returns. Further, we demonstrate that our results are different from the results reported by LSV 
who report that the value strategies outperform glamour strategies. Moreover, our results are robust to value-weighted returns.

We believe that the results reported in this paper will be of interest from both the practitioners' and academicians' point of view.

\section{References}

Abarbanell, J., and R. Lehavy, 2003, Biased forecast or biased earnings: the role of earnings management in explaining apparent optimism and inefficiency in analyst forecast errors, Journal of Accounting and Finance 36, 105-146.

Affleck-Graves, J., and R. Miller, 2003, The information contents of calls of debt: evidence from long run stock returns, Journal of Financial Research 26, 421-447.

Bali, T., N. Cakici, and R. F. Whitelaw, 2011, Maxing out: stocks as lotteries and the cross-section of expected returns, Journal of Financial Economics 99, 427-446.

Banz, R., 1981, The relationship between returns and market value of common stocks, Journal of Financial Economics 9, 3-18.

Bolton, P., J. Scheinkman, and W. Xiong, 2006, Executive compensation and short term behavior in speculative market, Review of Economic Studies 73, 557-610.

Brown, L., 1998, Managerial behavior and the bias in analysts' earnings forecasts, Working paper.

Campello, M., 2003, Capital structure and product markets interactions: evidence from business cycles, Journal of Financial Economics 68, 353-378.

Campello, M., 2006, Debt financing: Does it boost or hurt firm performance in product markets, Journal of Financial Economics 82, 135-172.

Carhart, M., 1997, On persistence in mutual fund performance, Journal of Finance 52, $57-82$.

Chan, L., N. Jegadeesh, and J. Lakonishok, 1999, The profitability of momentum strategies, Financial Analyst Journal 55, 80-90.

Chen, J., 2012, Risk based explanation of the book-to-market effect, Accounting and Finance 52, 137-154.

Chordia, T., and L. Shivakumar, 2006, Earnings and price momentum, Journal of Financial Economics 80, 627-656.

Cooper, M., H. Gulen, and M. Schill, 2008, Asset growth and the cross section of stock returns, Journal of Finance 68, 1609-1651.

Cremer, M., A. Pareek, and Z. Sautner, 2016, Short term investors, long term investments and firm value, Working paper (Frankfurt School of Finance and Management).

Fama, E., and K. French, 1992, The cross-section of expected stock returns, Journal of Finance 47, 427-465.

Fama, E., and K. French, 1993, Common risk factors in the returns of stocks and bonds, Journal of Financial Economics 33, 3-56.

Fresard, L., 2010, Financial strength and product market behavior: the real effects of corporate cash holdings, Journal of Finance 65, 1097-1122.

Jegadeesh, N., and S. Titman, 1993, Returns to buying winners and selling losers: implications for stock market efficiency, Journal of Finance 48, 65-91.

Lakonishok, J., A. Shleifer, and R. Vishny, 1994, Contrarian investment, extrapolation, and risk, Journal of Finance 49, 1541-1578.

Lipson, M., S. Mortal, and M. Schill, 2009, What explains the asset growth effect in stock returns?, Working paper (University of Virginia).

Livant, J., and R. Mendenhall, 2006, Comparing the post earnings announcement drift for surprises calculated from analyst and time series forecast, Journal of Accounting Research 44, 177-205. 
Loughran, T., and J. Ritter, 1995, The new issues puzzle, Journal of Finance 50, 23-51.

Michaely, R., R. Thaler, and K. Womack, 1995, Price reaction to dividend initiations and omissions: overreaction or drift?, Journal of Finance 50, 573-608.

Polk, C., and P. Sapienza, 2009, The stock market and corporate investment: a test of catering theory, Review of Financial Studies 22, 187-217.

Rau, R., and T. Vermaelen, 1998, Glamour, value and the post-acquisition performance of acquiring firms, Journal of Financial Economics 49, 223-253.

Reinganum, M., 1981. The anomalous stock market behavior of small firms in January, Journal of Financial Economics 12, 89-104.

Scherbina, A., 2008, Suppressed negative information and future underperformance, Review of Finance 12, 533-565.

Skinner, D., and R. Sloan, 2002, Earnings surprises, growth expectations, and stock returns or don't let an earnings torpedo sink your portfolio, Review of Accounting Studies 7, 289-312.

Spiess, K., and J. Affleck-Graves, 1999, The long-run performance of stock returns following debt offerings, Journal of Financial Economics 54, 45-73. 